Annals of Warsaw University of Life Sciences - SGGW

Land Reclamation No 48 (4), 2016: 341-351

(Ann. Warsaw Univ. Life Sci. - SGGW, Land Reclam. 48 (4), 2016)

\title{
Threats to aquatic ecosystems caused by antibiotic-resistant isolate of Escherichia coli from sewage
}

\author{
MAGDALENA FRĄK, ZUZANNA KOZERSKA \\ Department of Environmental Improvement, Warsaw University of Life Sciences - SGGW
}

\begin{abstract}
Threats to aquatic ecosystems caused by antibiotic-resistant isolate of Escherichia coli from sewage. The occurrence of Escherichia co$l i$ isolate resistant to penicillin and streptomycin in sewage discharged into the environment was tested. Thirty three Escherichia coli isolate were isolated from sewage samples showed different susceptibility to tested antibiotics. All tested isolate show higher resistance to penicillin than streptomycin. Twenty four tested E. coli isolate showed resistance only to low concentrations of penicillin. Five E. coli isolate showed resistance to higher concentrations of penicillin as well $\left(120 \mu \mathrm{g} \cdot \mathrm{dm}^{-3}\right)$. Five E. coli isolate showed resistance to penicillin and streptomycin. Discharging sewage that contains bacteria isolate resistant to antibiotics into the aquatic environment causes their spreading and increases threats to aquatic ecosystems.
\end{abstract}

Key words: antibiotic-resistant, sewage, Escherichia coli, penicillin, streptomycin

\section{INTRODUCTION}

Antibiotics are chemical compounds with a complicated and highly differentiated structure, they are biologically active in living organisms (Bartelmus et al. 2014). Their basic aim in medical procedure is to enter pathogen cells and to inhibit their metabolism (Harnisz 2015). An organism that is being treated does not completely metabolize anti- biotics, so they are excreted in their active form and released into the environment, including household sewage (Zabłotni and Jaworska 2014). Also expired or unused medicines, which are thrown away directly into landfill sites or are flushed down into common sewerage system might be a vital source of antibiotics in sewage. Antibiotics are commonly applied not only in medical procedure, but also in farming (Damaziak et al. 2014) and veterinary procedure (penicillin, chlortetracycline, oxytetracycline (Dibner and Richards 2005).

The application of organic fertilizers, produced from animal waste, might also cause the presence of antibiotics residues in natural waters. Animals excrete the excess of antibiotics, which is why antibiotics are present in cesspit, slurry and manure. Using contaminated animal waste might result in migration of antibiotics directly from the fields fertilized with them to aquatic ecosystems (Kümmerer 2003). Medicines, which are not absorbed by living organisms, accumulate in bottom sediment or they might spread into far distances (Kruszelnicka et al. 2012). 
It is impossible for the currently applied standard methods of sewage treatment to fully eliminate antibiotics residues. The probable reason is their low concentration which makes it difficult for inhibition and chemical precipitation to occur. The lack of susceptibility of antibiotics to biological decomposition is also the result of the lack of polar structure and their differentiated activity (Białk and Stepnowski 2015). This makes it impossible for microorganisms to produce enzymes that metabolize antibiotics. Antibiotics that are not retained in the process of sewage treatment reach the environment, including ground waters. Moreover, once antibiotics are present in sewage residues, they might reach the soil and then natural waters as a result of being stored or recycled (Bartelmus et al. 2014).

The most commonly identified antibiotics in aquatic environment are as follows: penicillin, erythromycin, ciprofloxacin, tetracycline, sulfamethoxazole (Kümmerer 2003). These substances pose a serious threat to ground waters. They show among others impact on tissue structures, they can lead to changes in the functioning of living organisms (Kruszelnicka et al. 2012), diversification of sewage microflora, inhibition of the growth of living tissues and also synthesis of DNA, RNA and proteins (Łebkowska 2009). The constant presence of even small amounts of antibiotics in sewage causes slow development of resistant isolate, which are then released into sewage receiving rivers. Their spreading causes growth of resistant micro-organisms, which transmit a newly developed feature to next generations. The features of resistance might be transmitted from resistant tissues to susceptible ones among bacteria that belong to the same species or to other species as well (Łebkowska 2009).

The experiment deals with the occurrence of antibiotic-resistant Escherichia coli isolate in household sewage discharged to aquatic ecosystems. These bacteria are gram-negative and belong to Enterobacteriaceae. They are the main component of physiological flora of the large intestine of humans and warmblooded animals and that is why the bacteria is excreted with waste into the environment. As a result, they are permanently and typically present in water, soil and bottom sediment. Escherichia coli is a typical opportunistic pathogen, which can cause among others food poisoning (Muhammad et al. 2009, Frąk 2013). It shows changeable resistance to medicines in people and animals. Moreover, it acquires resistance significantly faster than other bacteria, which additionally causes dissemination of acquired features (Tadesse et al. 2012). Escherichia coli actively takes part in sewage treatment processes (processes of nitrogen reduction) and it is discharged in huge amounts to aquatic ecosystems (Frąk 2013).

The aim of the research is to show the presence of Escherichia coli isolate 
resistant to penicillin and streptomycin in domestic sewage and the assessment of the grade of threat to aquatic environment posed by their disposal. The analysis of sensitivity of isolators to different concentrations of tested antibiotics was also conducted.

\section{MATERIAL AND METHODS}

Samples of wastewater treatment effluent, discharged to aquatic ecosystems (watercourse), were collected from three randomly selected sewage treatment plants located in Masovian Voivodship (Poland). All wastewater treatment plants are mechanical-biological wastewater treatment plants that apply the activated sludge process. They receive sewage from the surrounding towns and industrial wastewaters: wastewater treatment plant No $1-3 \%$ (fruit and vegetable processing industry); wastewater treatment plant No $2-38 \%$ (food industry: meat, dairy, fruit and vegetable processing); wastewater treatment plant No $3-5 \%$ (fruit and vegetable processing industry). In all wastewater treatment plants the degree of reduction of contamination of sewage meets the requirements of the Regulation of the Minister of Environment from 2014 (Dz.U. 2014, poz. 1800). The basic characteristics of the wastewater treatment plants are presented in Table.

Isolate identified as belonging to Escherichia coli species were isolated from the samples. In the first stage of isolation Eijkman test was conducted, in
TABLE. Basic technological parameters of the tested wastewater treatment plants

\begin{tabular}{|l|c|c|c|}
\hline Indicators & No 1 & No 2 & No 3 \\
\hline $\begin{array}{l}\text { Average daily flow } \\
\left(\mathrm{m}^{3} \cdot \text { day }^{-1}\right)\end{array}$ & 12000 & 11000 & 13000 \\
\hline ENI & 79500 & 58000 & 76000 \\
\hline \multicolumn{4}{|c|}{ Degree of reduction of contamination } \\
of sewage (\%) \\
\hline $\mathrm{COD}_{\mathrm{Cr}}$ & 96.0 & 97.9 & 98.0 \\
\hline $\mathrm{BOD}_{5}$ & 99.3 & 99.6 & 99.5 \\
\hline Total nitrogen & 89.7 & 90.1 & 92.0 \\
\hline Total phosphorus & 99.0 & 90.7 & 95.5 \\
\hline Total suspension & 99.7 & 98.2 & 98.7 \\
\hline
\end{tabular}

which $0.1 \mathrm{ml}$ of the tested sewage was incubated. Fluid cultures were incubated at $44^{\circ} \mathrm{C}$. After $24 \mathrm{~h}$ the cultivated tissues underwent selective isolation test, Endo, agar $\mathrm{mFC}$, MacConkey agar and Levin agar. The streak plate method was applied and the cultures were cultivated at $37^{\circ} \mathrm{C}$. Based on distinctive features selected cultivated cultures were classified as $E$. coli. Serial passage was performed to isolate cultures. Research was conducted in the period April-July 2016.

In the second stage of the experiment E. coli isolate were randomly selected: eight isolate from sewage treatment plant No 1, 13 from sewage treatment plant No 2 and 12 from sewage treatment plant No 3. These isolate underwent susceptibility testing to penicillin (Penicillinum Crystallisatum TZF) and streptomycin (Streptomycinum TZF). Disc diffusion method was applied. Concentrations of antibiotics were tested $\left[\mu \mathrm{g} \cdot \mathrm{dm}^{-3}\right]: 10,50$, $100,120,150,170,200$. The cultures were incubated at $37^{\circ} \mathrm{C}$ for $24 \mathrm{~h}$ and then inhibition zones were observed, which proves the occurrence of susceptibility. 


\section{RESULTS}

The presence and number of Escherichia coli tissues were estimated in the tested samples from three selected sewage treatment plants. Their average number per $1 \mathrm{ml}$ of wastewater treatment effluent was marked as $12 \cdot 10^{5}-10 \cdot 10^{6} \mathrm{CFU}$. Thirty three isolate were randomly selected out of the isolated Escherichia coli and underwent a test for susceptibility to penicillin and streptomycin. The isolate resistance to antibiotics was assessed based on the lack of clear-zone (where bacteria have not grown) around the diffusion disc. The grade of susceptibility was defined based on the following parameters: " 0 " means a complete lack of susceptibility (that is the occurrence of resistance symptoms) to the tested antibiotic concentration, and " 5 " means very high susceptibility (that is a wide zone of growth inhibition around discs).

Figures 1-7 present the results of tests that define the grade of resistance of E. coli isolate (K1-K33) to tested penicillin and streptomycin solutions at concentrations $\left[\mu \mathrm{g} \cdot \mathrm{dm}^{-3}\right]: 10,50,100$,
$120,150,170,200$. The isolate were isolated from wastewater treatment effluent samples collected from three sewage treatment plants (sampl 1, 2 and 3). The results indicate that all tested Escherichia coli isolate show different sensitivity to tested antibiotics.

Eight E. coli isolate were isolated from sample No 1 (sewage treatment plant No 1): K1-K8 (Figs 1-7), which underwent tests for resistance to penicillin and streptomycin. The analyses showed that all isolate display features of resistance to penicillin in concentrations 10 (Fig. 1) and $50 \mu \mathrm{g} \cdot \mathrm{dm}^{-3}$ (Fig. 2). Additionally, five of them (K1, $\mathrm{K} 2, \mathrm{~K} 3, \mathrm{~K} 4, \mathrm{~K} 5$ ) showedresistancetoconcentrations 100 (Fig. 3) and $120 \mu \mathrm{g} \cdot \mathrm{dm}^{-3}$ (Fig. 4); four isolate (K2, K3, K4, K5) showed resistance to concentrations 150 (Fig. 5) and $170 \mu \mathrm{g} \cdot \mathrm{dm}^{-3}$ (Fig. 6). All tested isolate (Fig. 7) showed susceptibility to penicillin at concentration 200 $\mu \mathrm{g} \cdot \mathrm{dm}^{-3}$. Resistance of $E$. coli to streptomycin occurred in five isolate $(\mathrm{K} 2, \mathrm{~K} 3$, $\mathrm{K} 4, \mathrm{~K} 5, \mathrm{~K} 7)$ at $10 \mu \mathrm{g} \cdot \mathrm{dm}^{-3}$ concentration (Fig. 1), three isolate (K2, K3, K4)

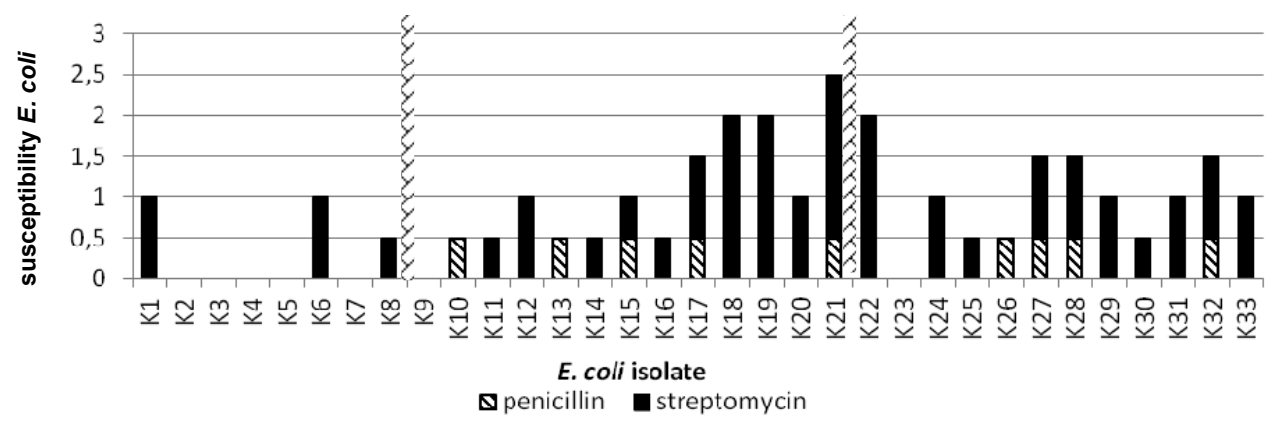

FIGURE 1. Resistance of Escherichia coli isolate to penicillin and streptomycin at concentration $10 \mu \mathrm{g} \cdot \mathrm{dm}^{-3}$ 


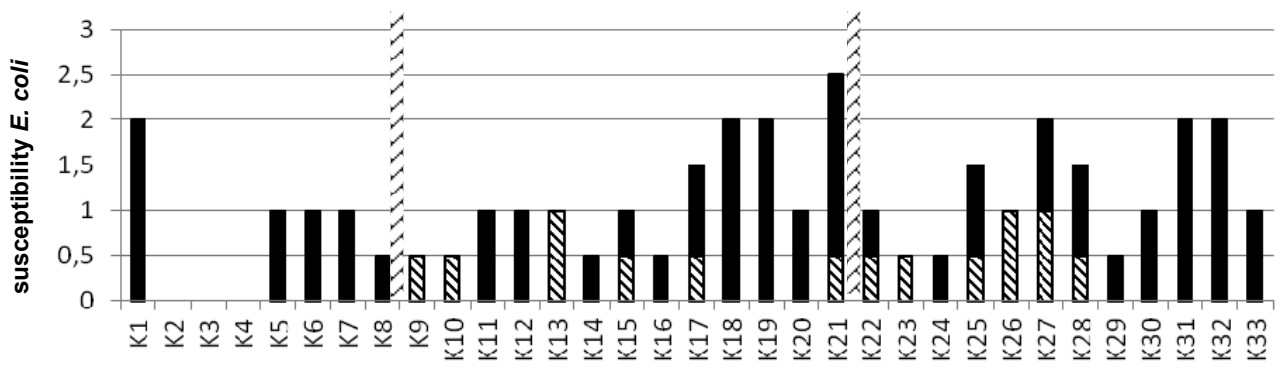

E. coli isolate

$\mathbf{\nabla}$ penicyllin $\mathbf{D}$ streptomycin

FIGURE 2. Resistance of Escherichia coli isolate to penicillin and streptomycin at concentration $50 \mu \mathrm{g} \cdot \mathrm{dm}^{-3}$

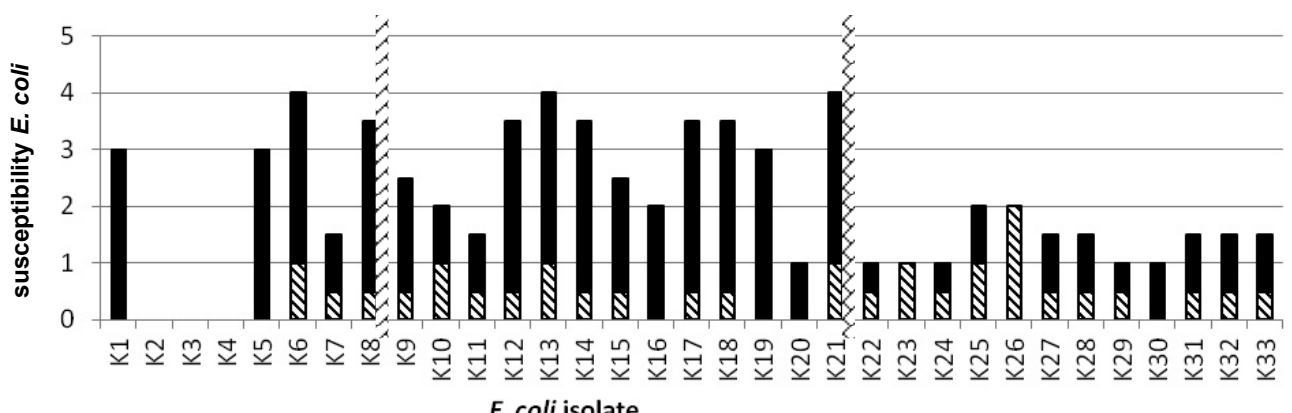

E. coli isolate

\$penicillin

- streptomycin

FIGURE 3. Resistance of Escherichia coli isolate to penicillin and streptomycin at concentration $100 \mu \mathrm{g} \cdot \mathrm{dm}^{-3}$

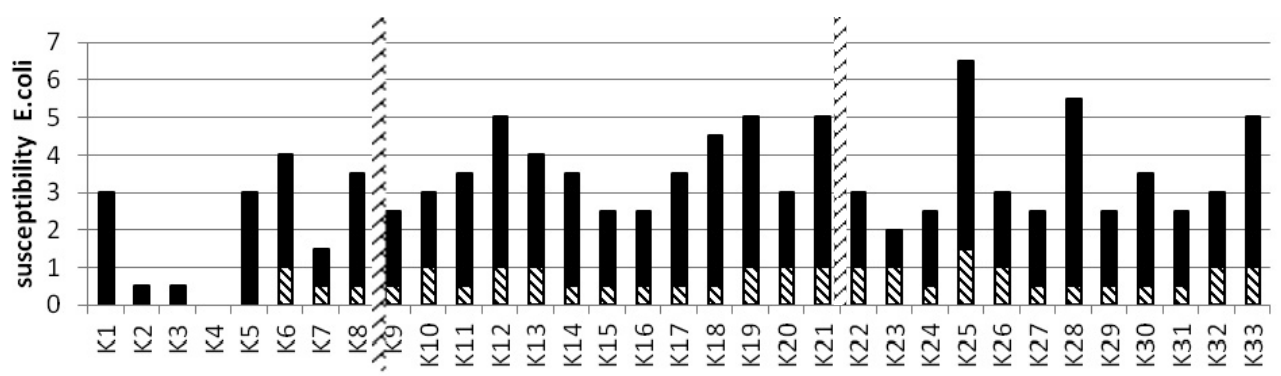

E. coli isolate

Qpenicillin $\mathbf{m}$ streptomycin

FIGURE 4. Resistance of Escherichia coli isolate to penicillin and streptomycin at concentration $120 \mu \mathrm{g} \cdot \mathrm{dm}^{-3}$ 


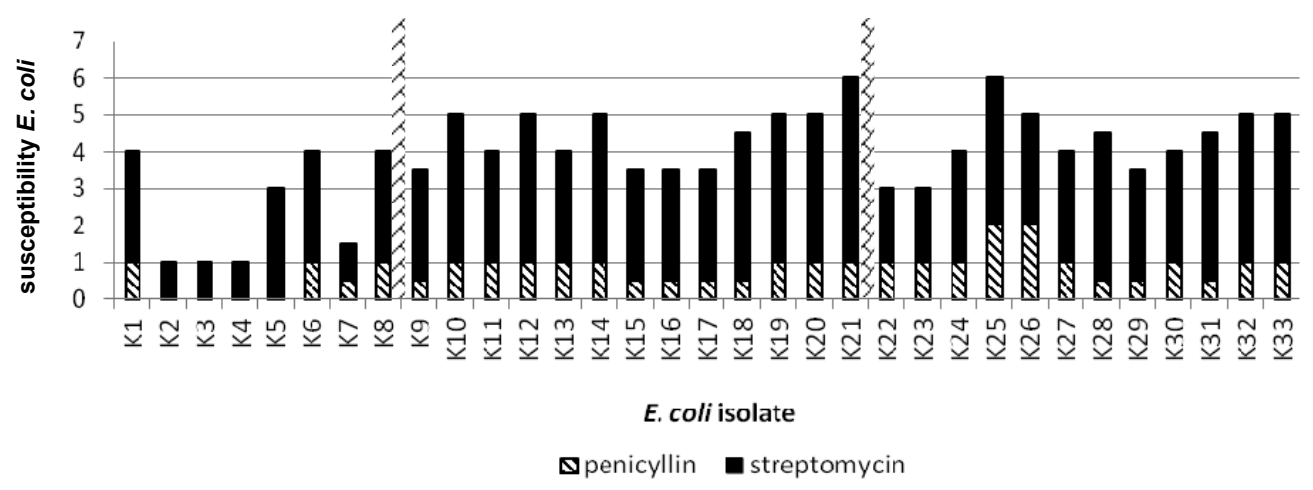

FIGURE 5. Resistance of Escherichia coli isolate to penicillin and streptomycin at concentration $150 \mu \mathrm{g} \cdot \mathrm{dm}^{-3}$

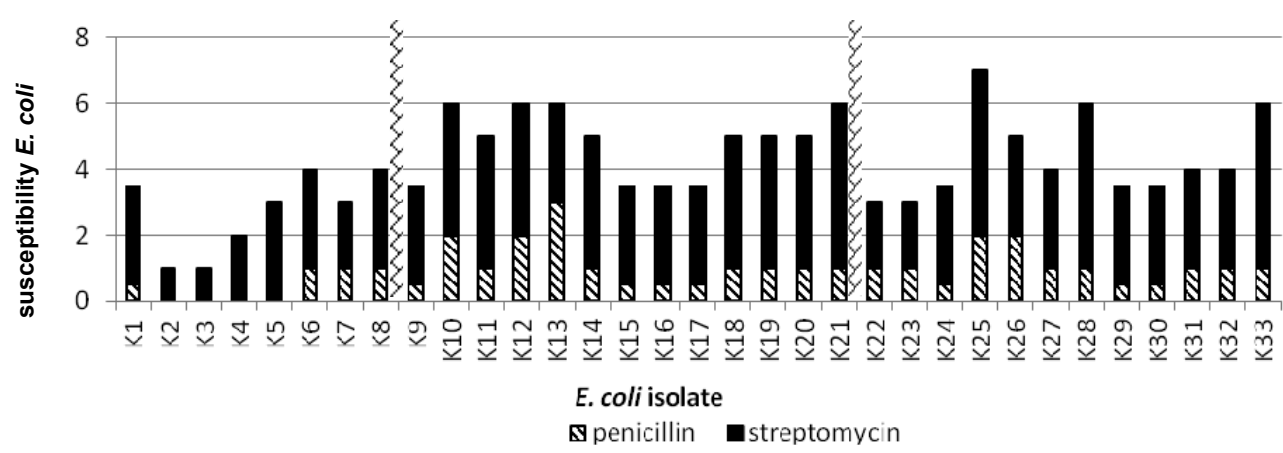

FIGURE 6. Resistance of Escherichia coli isolate to penicillin and streptomycin at concentration $170 \mu \mathrm{g} \cdot \mathrm{dm}^{-3}$

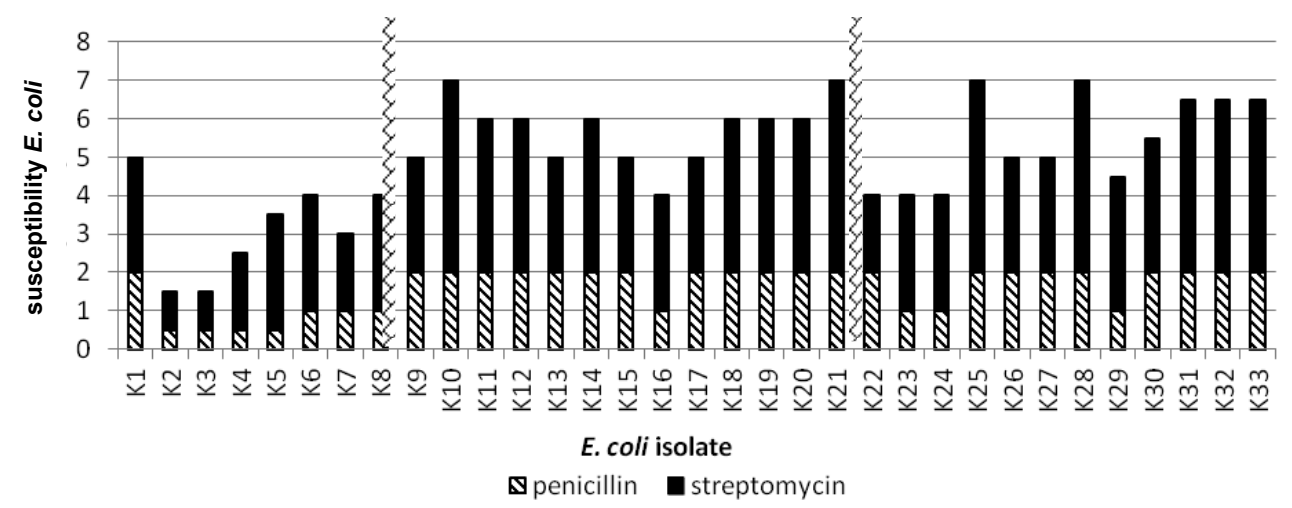

FIGURES 7. Resistance of Escherichia coli isolate to penicillin and streptomycin at concentration $200 \mu \mathrm{g} \cdot \mathrm{dm}^{-3}$ 
at concentrations 50 (Fig. 2) and $100 \mu \mathrm{g}$. $\cdot \mathrm{dm}^{-3}$ (Fig. 3), and in one isolate (K4) at concentration $120 \mu \mathrm{g} \cdot \mathrm{dm}^{-3}$ (Fig. 4). All tested isolate (K1-K8) showed differentiated susceptibility to concentrations 150,170 and $200 \mu \mathrm{g} \cdot \mathrm{dm}^{-3}$ (Figs 6, 7,8). Escherichia coli isolate isolated from sewage sample No 1 show higher resistance to penicillin than streptomycin (Fig. 8). centrations 10 and $50 \mu \mathrm{g} \cdot \mathrm{dm}^{-3}$ three resistant isolate were registered $(\mathrm{K} 9, \mathrm{~K} 10$, K13) (Figs 1 and 2), and the other ones $\left(100,120,150,170\right.$ and $\left.200 \mu \mathrm{g} \cdot \mathrm{dm}^{-3}\right)$ showed the lack of resistance to streptomycin (Figs 3-7). It was noticed again that $E$. coli shows higher resistance to penicillin than to streptomycin.

Twelve E. coli (K22-K33) isolate were separated from sample No 3 (sewage treatment plant No 3). Resistance

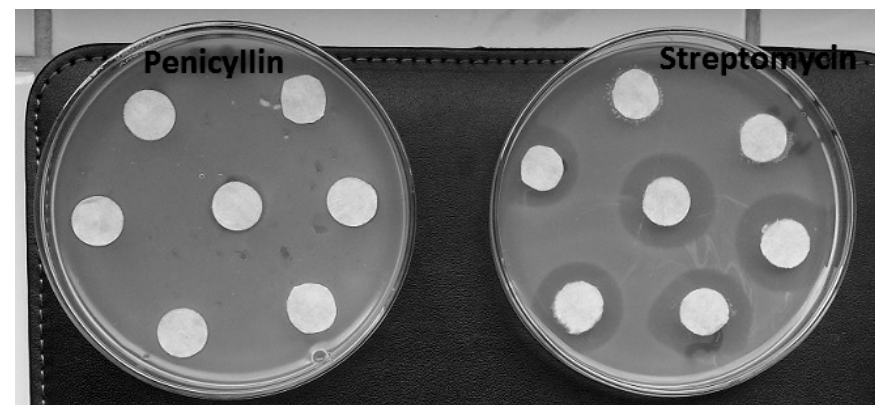

FIGURE 8. Examples of cultures depicting differences in susceptibility of the tested Escherichia coli isolate (in the photograph: Escherichia coli cultures isolate K5)

Thirteen E. coli (K9-K21) isolate were collected from sample No 2 (sewage treatment plant No 2). Resistance to penicillin was observed in eight E.coli isolate (Fig. 1) (K9, K11, K12, K14, $\mathrm{K} 16, \mathrm{~K} 18, \mathrm{~K} 19, \mathrm{~K} 20)$ at concentration $10 \mu \mathrm{g} \cdot \mathrm{dm}^{-3}$ and seven isolate $(\mathrm{K} 11, \mathrm{~K} 12$, K14, K16, K18, K19, K20) at concentration $50 \mu \mathrm{g} \cdot \mathrm{dm}^{-3}$ (Fig. 2). Only three resistant isolate (K16, K19, K20) were observed (Fig. 3) in dilute $100 \mu \mathrm{g} \cdot \mathrm{dm}^{-3}$, whereas all other tested isolate showed the lack of resistance to concentrations 120, 150, 170 and $200 \mu \mathrm{g} \cdot \mathrm{dm}^{-3}$ (Figs 4, 5, $6,7)$. In the case of streptomycin, at con- to penicillin was observed in eight isolate (K22, K23, K24, K25, K29, K30, $\mathrm{K} 31, \mathrm{~K} 33$ ) at concentration $10 \mu \mathrm{g} \cdot \mathrm{dm}^{-3}$ (Fig. 1); six isolate at concentration $50 \mu \mathrm{g} \cdot \mathrm{dm}^{-3}(\mathrm{~K} 24, \mathrm{~K} 29, \mathrm{~K} 30, \mathrm{~K} 31$; K32, $\mathrm{K} 33$ ) (Fig. 2) and in one isolate (K30) at concentration $100 \mu \mathrm{g} \cdot \mathrm{dm}^{-3}$ (Fig. 3). All E. coli isolate showed susceptibility to penicillin at concentrations 120,150 , 170 and $200 \mu \mathrm{g} \cdot \mathrm{dm}^{-3}$ (Figs 4, 5, 6, 7). As far as isolates exposed to streptomycin are concerned, two resistant isolate were observed (K23, K26) at concentrations 10 (Fig. 1) and $50 \mu \mathrm{g} \cdot \mathrm{dm}^{-3}$ (Fig. 2). All the bacteria in solutions at concentrations $100,120,150,170$ and $200 \mu \mathrm{g} \cdot \mathrm{dm}^{-3}$ 
(Figs 3, 4, 5, 6, 7) showed the lack of resistance. Again higher resistance of E. coli to penicillin was observed.

The results indicate that tested sewage contain different Escherichia coli isolate, which indicate differentiated susceptibility to tested antibiotics. The highest susceptibility of isolate (the largest clear-zone) was observed at concentration $200 \mu \mathrm{g} \cdot \mathrm{dm}^{-3}$ (Fig. 7). The majority of tested isolate showed higher resistance to antibiotics at concentration $10 \mu \mathrm{g} \cdot \mathrm{dm}^{-3}$ (Fig. 1). The highest number of isolate resistant to tested drugs was observed in sewage from sewage treatment plant No 1 and the lowest in sewage from sewage treatment plant No 3 .

\section{DISCUSSION}

Harnisz (2015) is stated that 11 of wastewater treatment effluent discharged to ground waters contains on average $20 \mu \mathrm{g}$ penicillin. The following article shows that 24 out of 33 isolated E. coli isolate are resistant to this antibiotic at concentration $10 \mu \mathrm{g} \cdot \mathrm{ml}^{-1}$. The results of tests found in literature indicate (Kümmerer 2003, Łebkowska 2009, Kruszelnicka et al. 2012), that antibiotics constantly present in the environment cause fast acquisition of resistance features by bacteria to a given active substance. It might be inborn resistance, in which case it comes to inhibition of antibiotics activity inside the bacteria cell or acquired resistance as a result of a horizontal transfer between micro-organism. The results based on the following study indicate and confirm the occurrence of E. coli isolate, which are resistant to low concentrations of penicillin, in sewage discharged to the environment. Besides, isolate $\mathrm{K} 2, \mathrm{~K} 3, \mathrm{~K} 5$ and $\mathrm{K} 8$ showed resistance to penicillin even at concentration $150 \mu \mathrm{g} \cdot \mathrm{dm}^{-3}$. According to Buczek and Marć (2009), bacteria gram-negative often show resistance to penicillin. These results prove that in the tested sewage (sample No 1) E. coli isolate resistant to penicillin are present. The results suggest also potential threats to the aquatic environment posed by dissemination of this feature. Tests indicate that also Chironomidae show features of resistance to penicillin in aquatic environment (Kozerska 2016).

In all cultivated cultures at penicillin concentration amounting to $200 \mu \mathrm{g} \cdot \mathrm{dm}^{-3}$ the lack of inhibition zone around the diffusion disc was observed. This suggests the lack of resistance features. However, the lack of inhibition zone might also result from structural or physiological changes of tissues. High antibiotics concentration influences the changes in osmotic pressure of aqueous solutions and at the same time plasmolysis processes (Sochacka and Boratyński 2011). At permanently high concentrations this process is irreversible and leads to the death of a tissue. A high concentration of antibiotics can also influence the processes of protein denaturation, which also causes death of tissues (Sochacka and Boratyński 2011). 
It was stated in the research that E. coli isolate (coming from three sewage treatment plants) show resistance to streptomycin as well. Ten isolate resistant to streptomycin at concentration $10 \mu \mathrm{g} \cdot \mathrm{dm}^{-3}$ were identified, eight - at concentration $50 \mu \mathrm{g} \cdot \mathrm{dm}^{-3}$, three- at concentration $100 \mu \mathrm{g} \cdot \mathrm{dm}^{-3}$ and one at concentration $120 \mu \mathrm{g} \cdot \mathrm{dm}^{-3}$. As it was the case with experiments on penicillin, all tested $E$. coli isolate (33) showed the lack of growth in the presence of streptomycin at concentration $200 \mu \mathrm{g} \cdot \mathrm{dm}^{-3}$. Probably, the reason of the noticed clear-zone is also too high concentration of the chemical substance that influences environmental conditions that negatively impact the life of a tissue. Isolate $\mathrm{K} 2, \mathrm{~K} 3, \mathrm{~K} 4$ and $\mathrm{K} 5$ are resistant to both tested antibiotics.

Numerous scientific sources indicate (Zhao et al. 2001, Giammanco et al. 2002, Januszkiewicz 2012), that E. coli shows resistance to minimum one antibiotic, often including streptomycin. The results can be different because bacteria belong to the gram-negative group, which reacts changeably to the applied antibiotic. It is caused by differences among representatives of specific serotypes. Escherichia coli showing resistance to antibiotics came from hospital sewage, which suggests differentiated ability to produce pathogenic factors. What is more, environmental, climatic conditions and the level of economic development could have influenced the overall result. In the research carried out by Tadesse et al. (2012) it was also shown that a lot of $E$. coli isolate are resistant to a couple of antibiotics at the same time, including streptomycin. This resistance amounts to $34.2 \%$. It might be caused by differentiated source of isolates (human or animal). Already in 1934 streptomycin was applied in medicine - it suggests that the phenomenon of resistance underlies constant progression. Buczek and Marć (2009) indicates that one in 109 Escherichia coli tissues acquires resistance to this kind of medicine at high concentrations of streptomycin. The results are not explicit yet, however, as far as the results of the following article are concerned, a threat to the aquatic environment caused by the presence of Escherichia coli isolate resistant to antibiotics in sewage can be confirmed.

In the available scientific literature there is little information concerning the influence of streptomycin on other aquatic organisms: only Kozerska (2016) shows high susceptibility of Daphnia magna to this antibiotic.

Resistance to penicillin and streptomycin was shown only among isolate isolated from sample No 1. It suggests different characteristics of this sewage. Having analyzed the sources of sewage disposed to sewage treatment plant No 1 it was observed that this object collects hospital wastewater from the local hospital. It is probable then that high concentrations of antibiotics are constantly present in the sewage, which has led to the development of resistant isolate (Zhao et al. 2001, Giammanco et al. 2002). 


\section{CONCLUSION}

The following article deals with the occurrence of Escherichia coli isolate resistant to penicillin and streptomycin in wastewater treatment effluent discharged to aquatic ecosystems. The development of antibiotics resistance in typical microflora of animals can result in the dissemination of this feature among aquatic organisms. The interaction between people and animals with natural waters can consequently lead to migration of isolate to living organism and at the same time to threats to health and difficulties in treatment. Current methods of sewage treatment cannot completely dispose of remains of antibiotics, that is why legal regulations of the amount of pharmaceuticals discharged to the environment from a sewage treatment plant should be introduced. Moreover, monitoring of data should be applied and in the case of threats appropriate sanctions should be imposed.

\section{REFERENCES}

BARTELMUS G., GĄSZCZAK, A., SZCZOTKA A. 2014: Substancje pochodzenia farmaceutycznego jako wyłaniające się zagrożenie dla środowiska wodnego [Pharmaceuticals in the aquatic environment]. Theses Inst. Chem. Eng. Sci. 18, 5-16.

BIAŁK A., STEPNOWSKI P. 2008: Analityka pozostałości farmaceutyków w żywności i próbkach środowiskowych [Analyst pharmaceutical residues in food and environmental samples]. University of Gdansk, Departament of Chemistry. LAB - Lab. App., Res. 13, 4, 6-14.

BUCZEK K., MARĆ M. 2009: Antybiotykooporność bakterii - przyczyny i skutki [Bacterial antibiotic resistance - reasons and effects]. Ann. Univ. Mariae Curie-Sktodowska, Sect. DD 64, 3, 1-8.

DAMAZIAK K., MICHALCZUK M., KUREK A. 2014: Effect of rearing system on the microbiological quality of Pekin P44 and Muscovy MR71 ducks bowel. Ann. Warsaw Univ. of Life Sci. - SGGW, Animal Sci. 53, 13-20.

DIBNER J., RICHARDS J. 2005: Antibiotic growth promoters in agriculture: history and mode of action. Poultry Sci. 84: 634-664.

FRĄK M. 2013: Escherichia coli as a potential indicator of Biebrza River enrichment sources. J. Water Land Devel. 19 (12-13), 31-38.

GIAMMANCO G.M., PIGNATO S., GRIMONT F. et al. 2002: Characterization of Shiga toxin-producing Escherichia coli O157:H7 isolated in Italy and in France. Clin. Microbiol. 40, 4619-4624.

HARNISZ M., KORZENIEWSKA E., KORZENIEWSKA A. 2013: Antibiotic resistant Escherichia coli in hospital and municipal sewage and their emission to the environment. Ecotoxicol. Environ. Saf. 91: 96-102.

JANUSZKIEWICZ A. 2012: Werotoksyczne pałeczki Escherichia coli - epidemiologia, chorobotwórczość, lekooporność [Verocytotoxigenic Escherichia coli - epidemiology, pathogenicity and antimicrobial resistance]. Exper. Med. Microbiol. 64, 4, 315-336.

KOZERSKA Z. 2016: Wpływ antybiotyków na środowisko wodne na podstawie wybranych testów toksyczności [The influence antibiotics on the water environment based on tosicity test selected]. Diploma thesis, Warsaw University of Life Sciences - SGGW, Warszawa [unpublished].

KRUSZELNICKA I., GINTER-KRAMARCZYK D., ZAJĄC A., ZEMBRZUSKA J. 2012: Problematyka obecności farmaceutyków w ściekach [The issue of the presence of pharmaceuticals in sewage]. Wodociagi - Kanalizacja 5, 96-99.

KÜMMERER K. 2003: Significance of antibiotics in the environment. J. Antimicrob. Chem. 52, 1, 5-7. DOI: 10.1093/jac/dkg293.

ŁEBKOWSKA M. 2009: Występowanie bakterii antybiotykoopornych w wodzie przeznaczo- 
nej do spożycia przez ludzi [Antibiotic Resistant Bacteria in Drinking Water]. Ochr. Środ. 31, 2, 11-15.

MUHAMMAD A., SAIDUL A., HASSAN S., MOMENA S. 2009: Antibiotic Resistance of Escherichia coli Isolated From Poultry and Poultry Environment of Bangladesh. Int. J. Food Safety 11, 19-23.

Rozporządzenie Ministra Środowiska z dnia 18 listopada 2014 r. w sprawie warunków, jakie należy spełnić przy wprowadzaniu ścieków do wód lub do ziemi, oraz w sprawie substancji szczególnie szkodliwych dla środowiska wodnego [Regulation of the Minister of Environment]. Dz.U. 2014, poz. 1800.

SOCHACKA M., BORATYŃSKI J., 2011: Osmoregulacja - ważny parametr rozwoju bakterii [Osmoregulation - an important parameter of bacterial growth]. Institute of Immunology and Experimental Therapy Pan names. Ludwika Hirszfelda we Wrocławiu. Postepy Hig. Med. Dosw. 65, 714-724.

TADESSE D., ZHAO S., TONG E., AYERS S., SINGH A., BARTHOLOMEW J., McDERMOT P. 2012: Antimicrobial Drug Resistance in Escherichia coli from Humans and Food Animals. United States, 1952-2002. Emerg. Infect. Dis. 18 (5), 741-749.

ZABŁOTNI A., JAWORSKI A. 2014: Źródła antybiotyków $\mathrm{W}$ środowiskach naturalnych $i$ ich rola biologiczna [Sources of antibiotics in natural environments and their biological role]. Postepy Hig. Med. Dosw. 68, 1040-1049.

ZHAO S., WHITE D.G., GE B. et al. 2001: Identification and characterization of integronmediated antibiotic resistance among Shiga toxin-producing Escherichia coli isolates. Appl. Environ. Microbiol. 67, 1558-1564.

Streszczenie: Zagrożenie ekosystemów wodnych przez antybiotykooporne szczepy Escherichia coli pochodzenia ściekowego. Podjęto badania dotyczące występowania w ściekach bytowych odprowadzanych do ekosystemów wodnych penicylinoopornych i streptomycynoopornych szczepów Escherichia coli. Przeprowadzono także analizę wrażliwości izolatów na różnorodne stężenia badanych antybiotyków. W doświadczeniu wykorzystano próbki ścieków oczyszczonych z trzech oczyszczalni ścieków komunalnych. Wyizolowano 33 szczepy zidentyfikowane jako Escherichia coli. Szczepy zostały poddane badaniu wrażliwości na streptomycynę i penicylinę (stężenia $\left[\mu \mathrm{g} \cdot \mathrm{ml}^{-1}\right]$ : 10, 50, 100, 120, 150, 170, 200), metodą dyfuzyjno-krążkową. Obserwowano strefy zahamowania wzrostu, a na ich podstawie określano stopień wrażliwości poszczególnych szczepów. Wykazano, że 24 spośród 33 badanych szczepów E. coli wykazało oporność genetyczną na penicylinę, a tylko 10 szczepów na streptomycynę. Szczepy te wykazywały cechy oporności względem niskich stężeń badanych antybiotyków $\left(10 \mu \mathrm{g} \cdot \mathrm{ml}^{-1}\right)$. Cztery szczepy wykazały oporność na penicylinę także w stężeniu nawet $150 \mathrm{ug} \cdot \mathrm{ml}^{-1}$. Stwierdzono, że wszystkie badane izolaty wykazały wrażliwość na penicylinę i streptomycynę w stężeniu $200 \mu \mathrm{g} \cdot \mathrm{ml}^{-1}$. Wykazanie w badanych próbkach ścieków oczyszczonych obecności licznych szczepów Escherichia coli opornych na antybiotyki wskazuje na duże zagrożenie ekosystemów wodnych, będących ich odbiornikami.

\section{MS received June 2016}

\section{Authors' addresses:}

Magdalena Frąk, Zuzanna Kozerska

Katedra Kształtowania Środowisk

Wydział Budownictwa i Inżynierii Środowiska SGGW

ul. Nowoursynowska 166, 02-787 Warszawa

Poland

e-mail:magdalena_frak@sggw.pl

zuzannakozerska@onet.pl 